\title{
Recurrence of Papillary Thyroid Cancer Suspected by High Anti-Thyroglobulin Antibody Levels and Detection of Peripheral Blood Thyroglobulin mRNA
}

\begin{abstract}
The amplification of thyroglobulin (TG) mRNA in peripheral blood of patients with thyroid cancer has been studied for almost one decade, but its real contribution for diagnosis of cancer relapse has not yet been established. In the present paper we report the case of a patient with papillary thyroid cancer with undetectable stimulated serum thyrogobulin levels after thyroid ablation. Follow-up showed the presence of high titers of anti-thyroglobulin antibodies and the presence of TG mRNA in a peripheral blood sample, while cervical ultrasound and thorax and cervical computerized tomography were negative. Reinvestigation confirmed lymph node metastases. Anti-TG antibodies progressively decreased after surgery for metastatic lymph nodes resection followed by radioiodine therapy. Although our recent findings show that patients with positive TG mRNA do not have increased risk of cancer recurrence after 24 months of follow-up, the presence of TG mRNA along with high anti-TG antibodies were important indicators that determined further extensive investigation of tumour relapse in this patient, since positron emission tomography scan was not available at our Institution. A methodological standardization that can distinguish specific from non-specific TG mRNA amplification might be of great interest for the follow-up of differentiated thyroid cancer, especially in patients with high levels of anti-TG antibodies. (Arq Bras Endocrinol Metab 2008; 52/8:1321-1325)
\end{abstract}

Keywords: Thyroid cancer; Relapse; Thyroglobulin mRNA; Thyroglobulin; Anti-TG antibody

\section{RESUMO}

Recorrência de Carcinoma Papilífero de Tireóide Suspeitada Devido a Presença de Títulos Elevados de Anticorpo Antitireoglobulina e Detecção de mRNA de Tireoglobulina em Sangue Periférico.

A amplificação de mRNA de tireoglobulina (TG) no sangue periférico de pacientes com câncer de tireóide tem sido estudada por quase uma década, mas a sua real contribuição para o diagnóstico do câncer ainda não foi estabelecida. No presente trabalho, relatamos o caso de uma paciente com carcinoma papilífero de tireóide com níveis séricos de TG indetectáveis após ablação com radioiodo. No seguimento apresentou títulos elevados de anticorpos anti-TG e a presença de mRNA TG em uma amostra de sangue periférico, enquanto a ultra-sonografia e as tomografias computorizadas de tórax e cervical foram negativas. Os níveis de anticorpos anti-TG diminuíram progressivamente após ressecção cirúrgica dos linfonodos seguida de terapia com radioiodo. Embora nossos achados recentes mostrem que pacientes com mRNA TG não apresentam risco aumentado de recorrência do câncer após 24 meses de seguimento, a presença de mRNA TG associada a altos títulos de anticorpos anti-TG foram importantes indicadores que determinaram o prosseguimento da investigação para recorrência tumoral nesta paciente, uma vez que não dispunhamos, na ocasião, e PET-Scan em nossa clinical case report

\author{
Sabrina Mendes Coelho \\ Alexandru Buescu \\ ROSSANA CORBO \\ DeNISE P. CARVALHO \\ MÁRIO VAISMAN
}

Serviço de Endocrinologia (SMC, AB, MV); Serviço de Medicina Nuclear (RC); Hospital

Universitário Clementino Fraga

Filho; Laboratório de Fisiologia

Endócrina Doris Rosenthal,

Instituto de Biofísica Carlos

Chagas Filho (SMC, DPC);

Universidade Federal do Rio de

Janeiro, Rio de Janeiro, RJ, Brasil. 
instituição. Uma padronização metodológica que permita distinguir entre amplificação de mRNA TG específica e inespecífica poderá ser de grande interesse no seguimento do carcinoma diferenciado da tireóide, especialmente naqueles com títulos elevados de anticorpos anti-TG. (Arq Bras Endocrinol Metab 2008; 52/8:1321-1325)

Descritores: Câncer de tireóide; Recorrência; mRNA tireoglobulina; Tireoglobulina; Anticorpo antitireoglobulina

\section{INTRODUCTION}

apillary and follicular carcinomas correspond to the majority of thyroid malignancies and are among the most curable cancers. However, although papillary cancer is indolent, it accounts for more than $50 \%$ of the deaths because of its high incidence (1).

Almost $70 \%$ of patients who died of thyroid cancer were initially considered disease-free. After diagnosis of local relapse the mortality rate is $12 \%$ and increases to $43 \%$ after distant metastases develop (1). Traditionally, patients are evaluated for recurrence of disease with whole-body ${ }^{131}$-I scan (WBS), measurement of basal and TSH-stimulated serum thyroglobulin (TG), and cervical ultrasonography (USG) (2). However, at least one-fourth of recurrences from DTC do not concentrate iodine, and could benefit of positron emission tomography scan (PET-scan). Another pitfall in the follow-up of thyroid cancer is the fact that about $20 \%$ of patients with local recurrence and $5 \%$ with distant metastases have undetectable serum TG during TSH suppressive therapy (3). Also, serum TG autoantibodie interfere with the measurement and corresponds to another difficulty for diagnosis of cancer recurrence (4).

In order to increase the sensitivity of the diagnosis of recurrent disease, amplification of TG mRNA by reverse transcription-polymerase chain reaction (RTPCR) was suggested as being able to detect circulating thyroid cells, as first suggested (5).

We report herein the case of a patient with papillary thyroid cancer, negative post-therapeutic whole body scan, no suggestive images of local or distant metastases, undetectable stimulated serum TG with positive anti-TG antibodies. The patient would benefit of PETscan for analysis of tumour recurrence, however this diagnostic approach was not available at our Institution. The presence of TG mRNA in peripheral blood was another indication of tumour recurrence.

\section{SUBJECTS AND METHODS}

A 63-year-old man had undergone subtotal thyroidectomy for a thyroid nodular lesion in August 1999, with negative anti-TPO antibodies measured in 2000 and 2004. After the diagnosis of papillary thyroid carcinoma (T2N1M0), a total thyroidectomy was performed in October 1999, followed by radioiodine ablation with $100 \mathrm{mCi}^{131}$-I in March 2000; a post-therapy whole body scan showed only cervical uptake. Stimulated serum TG obtained after thyroxine withdrawal $(\mathrm{TSH}=$ $73.9 \mu \mathrm{UI} / \mathrm{mL}$ ) was $0.65 \mathrm{ng} / \mathrm{mL}$. Serum TG measurement was done using a commercial immunometric (IMA) chemoluminescence assay with analytic sensitivity of $0.2 \mathrm{ng} / \mathrm{mL}$, functional of $0.9 \mathrm{ng} / \mathrm{mL}$, inter- and intrassay variability less then $8.8 \%$ and $6 \%$, respectively, and normal reference values of $1.60-60 \mathrm{ng} / \mathrm{mL}$. The normal range of TSH was 0.4 to $4.0 \mu \mathrm{UI} / \mathrm{mL}$. Commercial anti-TG autoantibody assay (chemoluminescence) had analytic sensitivity of $10 \mathrm{IU} / \mathrm{mL}$, functional of $20 \mathrm{UI} / \mathrm{mL}$, interassay and intrassay variability less then $9.1 \%$ and $3.9 \%$, respectively, and normal values < $40 \mathrm{UI} / \mathrm{mL}$.

In June 2000 serum thyroglobulin was undetectable during suppressive TSH therapy, while serum antithyroglobulin antibodies were elevated $(681 \mathrm{U} / \mathrm{mL})$. From 2000 to 2004, extensive investigation was performed by whole body scans, cervical USG, thorax and cervical CT, but the site of tumor recurrence could not be detected. We then investigated the presence of TG mRNA in the patient's peripheral blood, in order to determine whether serum TG mRNA could be of value as a marker of recurrence.

Blood sample for RNA extraction was collected during TSH suppressive therapy. Total RNA was isolated from $3 \mathrm{ml}$ of whole blood. Blood sample was immediately mixed with $9 \mathrm{ml}$ of TRIzol in sterile tubes. Total RNA was extracted according to the manufacture's recommendation and then was quantified by 
measuring absorbance at $260 \mathrm{UV}$ light (Hitachi, U 3000). Four microgram of total RNA were reversely transcribed to complementary DNA (cDNA) that was precipitated with ethanol and ammonia acetate and then ressuspended. $25 \%$ of the cDNA was used in the subsequent qualitative PCR. The sample was assayed in duplicate. Glyceraldehyde-3-phosphate-dehydrogenase (GAPDH) expression was also determined in all samples to assess the integrity and quality of the RNA and cDNA (internal positive control). RT-negative controls for RT-PCR was performed to evaluated possible contamination. In order to prevent amplification of residual genomic DNA, the TG primers corresponded to nucleotide sequences in exons 2 and 4 , which are separated by 2 introns that together contain more than $2 \mathrm{~kb}$. PCR was performed as described by Ringel and cols. (5).

Standardization of RNA extraction and RT-PCR was done in a control group. Satisfactory amplification of specific DNA fragments of GAPDH (internal positive control) and TG was obtained in all ten normal subjects, as previously described (5).

Serum TG mRNA was positive and in January 2007, cervical US demonstrated 2 suspicious lymph nodes, and cytopathology after fine needle aspiration confirmed metastases. The patient was submitted to surgery and radioiodine therapy $(200 \mathrm{mci})$, and posttherapeutic dose WBS demonstrated no residual radioiodine uptake.

\section{DISCUSSION}

The prognosis of patients with thyroid cancer relapse depends, at least in part, on tumoral mass (6), so the earlier the diagnosis the best is the therapeutic response (7).

Serum TG is considered an excellent marker of thyroid recurrence. After recombinant TSH stimulation, a value less than $2 \mathrm{ng} / \mathrm{mL}$ has a high negative predictive value $(8,9)$. However, the principal limitation of serum TG measurement is the interference by anti-TG antibodies (anti-TGAb). A temporary rise in anti-TGAb level may occur during the first 6 months after radioiodine therapy, which might be a sign of the effectiveness of treatment, since anti-TGAb values return to original value or below after 6 months. In the absence of disease, anti-TGAb will progressively decrease and disappear within the first 2 years of follow-up (10). In contrast, anti-TGAb remained elevated in our patient, indicating tumor recurrence (Figure 1).

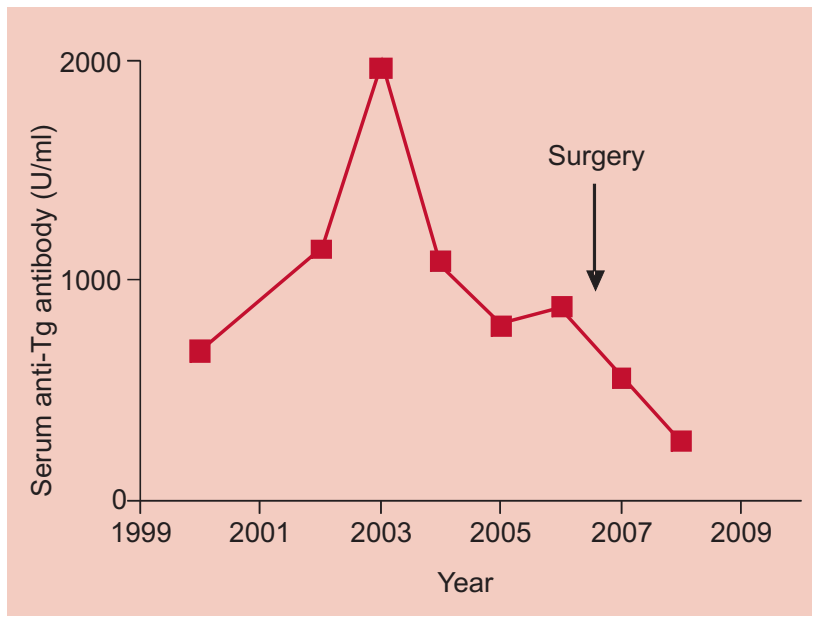

Figure 1. Serum anti-TG antibody levels in a patient with negative post-therapeutic WBS, cervical USG, thorax CT, with positive TG mRNA and cervical lymph nodes metastases, before and after their surgical removal followed by radioiodine therapy.

The possibility of detecting tumoral cells in peripheral blood using molecular biology techniques brought a new perspective for patients with DTC. Preliminary studies suggested that detection of TG mRNA had high sensitivity even during TSH suppressive therapy and would be particularly useful in the subgroup of patients with positive auto-antibodies. However, recent studies have showed less favorable results.

The measurement of circulating mRNA from thyroid tumor cells as a potential indicator of recurrent or persistent thyroid cancer was first introduced in the late 1990s $(5,11)$. In the first published study analyzing the TG mRNA in the peripheral blood as a tumor marker, Ditkoff and cols. (11) found sensitivity of $100 \%$ and specificity of $91 \%$. Similar results were more recently demonstrated $(12,13)$ after adequate selection of primers (sensitivity of $83.3 \%$ to $100 \%$ and specificity of 85.7 to $91.7 \%)$. The majority of studies included patients with papillary and follicular thyroid cancer and in some patients with poorly differentiated tumours were also evaluated, but Bellantone and cols. (14) observed that TG mRNA was detected only in patients with papillary thyroid cancer. No significant differences have been found for TG mRNA detection in patients with different tumour stages $(14,15)$.

One of the most important questions about the clinical applicability of TG mRNA detection in peripheral blood is the specificity of the method. In the majority of the studies, there are patients considered disease free in which TG mRNA is found in peripheral 
blood, suggesting a false positive result (16-19). However, it can be speculated that TG mRNA is a more sensitive test than traditional methods (serum TG, cervical US and WBS) and the presence of this mRNA might represent an increased risk of relapse, however some prospective studies have shown that TG mRNA does not predict the risk of relapse.

The method is based on several premises that must be validated. The first is that a sufficient number of cancer cells are consistently present in the circulation, even in the presence of minimal disease (sensitivity). The second major requirement for this test to be valid is that normal thyroid cells are never present in the circulation and that non-thyroid cells never express mRNA species (specificity). Normal thyroid cells express TG and significant amounts of its mRNA have been found in the peripheral blood of normal healthy controls (20). This suggests that the test may be valid only in patients with no normal thyroid tissue. Another more critical point is that TG mRNA may be expressed in very low concentrations by other cells in the body, including peripheral lymphocytes, through a process known as illegitimate transcription. Published studies suggest that neither of these two basic premises has been met by the currently available assays, given the low sensitivity and negative predictive value ( $82 \%$ and $43 \%$ respectively) reported in one study (16) and even lower specificity demonstrated in another (20). In view of the proven and potential pitfalls of measurement of circulating TG mRNA, and the lack of standardized methodology and large-scale well-controlled studies, these determinations must still be considered experimental.

In addition to the above mentioned low specificity, the use of TG mRNA test in the follow-up of patients with DTC has several disadvantages compared to serum TG, such as an elevated cost and large intra- and interassay variations. Takano and cols. (21) reported variation of 35 and $38 \%$, respectively.

While serum TG mRNA could be of value in patients with positive anti-TG antibodies, the presence of autoantibodies per se might suggest recurrence without the need of any other molecular tests (4).

No potencial conflict of interest to this article was reported.

\section{REFERENCE}

1. Mazzaferri EL, Massoll N. Management of papillary and follicular (differentiated) thyroid cancer: new paradigms using re- combinant human thyrotropin. Endocrine-Related Cancer. 2002;9:227-47.

2. Maia AL, Ward LS, Carvalho GA, Graf H, Maciel RM, Maciel LM, et al. Thyroid nodules and differentiated thyroid cancer: Brazilian consensus. Arq Bras Endocrinol Metab. 2007;51:867-93.

3. Schlumberger M, Pacini F. Thyroid tumors. Éditions Nucléon, Paris. 1999.

4. Spencer CA, Takeuchi M, Kazarosyan M, Wang CC, Guttler RB, Singer PA, et al. Serum thyroglobulin autoantibodies: prevalence, influence on serum thyroglobulin measurement, and prognostic significance in patients with differentiated thyroid carcinoma. J Clin Endocrinol Metab. 1998;83:1121-7.

5. Ringel MD, Ladenson PW, Levine MA. Molecular diagnosis of residual and recurrent thyroid cancer by amplification of thyroglobulin messenger ribonucleic acid in peripheral blood. J Clin Endocrinol Metab. 1998;83:4435-42.

6. Schlumberger M, Tubiana M, Vathaire F, Hill C, Gardet P, Travagli J-P, et al. Long-term results of treatment of 283 patients with lung and bone metastases from differentiated thyroid carcinoma. J Clin Endocrinol Metab. 1986;63:960-7.

7. Schlumberger M, Challeton C, De Vathaire F, Travagli JP, Gardet $P$, Lumbroso JD, et al. Radioactive iodine treatment and external radiotherapy for lung and bone metastases from thyroid carcinoma. J Nucl Med. 1996;37:598-605.

8. Robbins RJ, Chon JT, Fleisher M, Larson SM, Tuttle RM. Is the serum thyroglobulin response to recombinant human thyrotropin sufficient, by itself, to monitor for residual thyroid carcinoma? J Clin Endocrinol Metab 2002; 87:3242-7.

9. Mazzaferri EL, Robbins RJ, Spencer CA, Braverman LE, Pacini $F$, Wartofsky L, et al. A consensus report of the role of serum thyroglobulin as a monitoring method for low-risk patients with papillary thyroid carcinoma. J Clin Endocrinol Metab 2003;88:1433-41.

10. Chiovato L, Latrofa F, Braverman LE, Pacini F, Capezzone M, Masserini L, et al. Disappearance of humoral thyroid autoimmunity after complete removal of thyroid antigens. Ann Intern Med. 2003;139(5 Pt 1):346-51.

11. Ditkoff BA, Marvin MR, Yemul S, Shi YJ, Chabot J, Feind C, Lo Gerfo P. Detection of circulating thyroid cells in peripheral blood. Surgery. 1996;120:959-65.

12. Gupta MK, Taguba L, Areiaga R, Siperstein A, Faiman C, Mehta A, Reddy SSK. Detection of circulating thyroid cancer cells by reverse transcription-PCR for thyroid stimulating hormone receptor and thyroglobulin: the importance of primer selection. Clin Chem. 2002;48:1862-5.

13. Chinnappa P, Taguba L, Arciaga R, Faiman C, Siperstein A, Mehta $A E$, et al. Detection of thyrotropin-receptor messenger ribonucleic acid (mRNA) and thyroglobulin mRNA transcripts in peripheral blood of patients with thyroid disease: sensitive and specific markers for thyroid cancer. J Clinl Endocrinol Metab 2004;89:3705-9.

14. Bellantone $R$, Lombardi $C P$, Bossola $M$, Ferrante $A$, Princi $P$, Boscherini $M$, et al. Validity of thyroglobulin mRNA assay in peripheral blood of postoperative thyroid carcinoma patients in predicting tumor recurrences varies according to the histologic type. Cancer. 2001;92:2273-9.

15. Tallini G, Ghossein RA, Emanuel J, Gill J, Kinder B, Dimich AB, et al. Detection of thyroglobulin, thyroid peroxidase, and RET/ PTC1 mRNA transcripts in the peripheral blood of patients with thyroid disease. J Clin Oncol 1998;16:1158-66.

16. Elisei R, Vivaldi A, Agate L, Molinaro E, Nencetti C, Grasso L, et al Low specificity of blood thyroglobulin messenger ribonucleic acid assay prevents its use in the follow-up of differentia- 
ted thyroid cancer patients. J Clin Endocrinol Metab. 2004;89: 33-9.

17. Biscolla RP, Cerutti JM, Maciel RM. Detection of recurrent thyroid cancer by sensitive nested reverse transcription-polymerase chain reaction of thyroglobulin and sodium/iodide symporter messenger ribonucleic acid transcripts in peripheral blood. J Clin Endocrinol Metab. 2000;85:3623-7.

18. Bugalho MJ, Domingues RS, Pinto $A C$, Garrão $A$, Catarino $A L$, Ferreira T, et al. Detection of thyroglobulin mRNA transcripts in peripheral blood individuals with and without thyroid glands: evidence for thyroglobulin expression by blood cells. Eur J Endocrinol. 2001;145:409-13.

19. Francis T, Burch HB, Cai W, Lukes Y, Peele M, Carr FE, et al. Lymphocytes express thyrotropin receptor-specific mRNA as detected by the PCR technique. Thyroid. 1991;1:223-8.

20. Karavitaki N, Lembessis P, Tzanela M, Vlassopoulou V, Thalassinos $N$, Koutsilieris $M$. Molecular staging using qualitative
RT-PCR analysis detecting thyreoglobulin mRNA in the peripheral blood of patients with differentiated thyroid cancer after therapy. Anticancer Res. 2005;25(4):3135-42.

21. Takano T, Miyauchi A, Yoshida H, Hasegawa Y, Kuma k, Amino $\mathrm{N}$. Quantitative measurement of thyroglobulin mRNA in peripheral blood of patients after total thyroidectomy. $\mathrm{Br} \mathrm{J}$ Cancer. 2001;85:102-6.

\section{Correspondence to:}

Mario Vaisman

Rua General Venancio Flores 368 apt 302, Leblon 22441-090 Rio de Janeiro, RJ

E-mail: mario.vaisman@globo.com 